\title{
A Failure or \\ "A Very Great Public Service"? \\ Herbert Hoover, Iowa Banks, and the National Credit Corporation
}

\section{Calvin W. CoQuillette}

IN THE FALL OF 1931, following banking crises in Germany in July and Great Britain in September, the United States banking industry faced its own crisis of confidence. Perhaps the best indicator for measuring confidence, or the lack of it, was the number of bank failures. Bank failures nationwide were accelerating-dramatically. According to conventional wisdom, banks failed primarily because they lacked liquidity. After all, German banks and British banks - and their respective central bankshad not been able to maintain sufficient cash reserves to satisfy depositors; consequently, they were forced to declare moratoriums or renege on their commitment to pay in gold as the gold standard required. Believing that the problem of American banks could be reduced to a problem of liquidity, President Herbert Hoover proposed that the nation's banks form their own nationwide credit association to provide interbank liquidity loans. In October 1931 this corporation came to be known as the National Credit Corporation (NCC).

In mid-September, Hoover had good reason to believe that such an association of private-sector banks could at least check if not reduce the bank failure rate. First, he believed that banks, spearheaded by the New York City banks, could effectively spread liquidity throughout their industry. Second, he believed that a bank association could do so far more efficiently than a

I am grateful to the anonymous reviewers for the Annals of Iowa, whose comments helped me improve this article.

THE ANNALS OF IOWA 58 (Fall 1999). (C) The State Historical Society of Iowa, 1999. 
start-up government agency or the Federal Reserve System, which had less than one-third of all banks as members. Finally, he believed that because the liquidity problem affected only a few firms in a few industries (namely, farm banks, railroads, and some life insurance companies), formation of a new federal agency was premature. There was, to be sure, a federal precedent; the old War Finance Corporation, begun during World War I, had served as an engine of credit for the wartime economy. But Hoover was convinced initially that the proper role of the federal government was to persuade, not to coerce. The banks, he thought, certainly had the organization, resources, and capability to care for their own. Thus he established the National Credit Corporation to encourage "associationalism" among the banks. Sometime in mid-November, however, Hoover came to realize that federal resources would be required. The eventual result was the Reconstruction Finance Corporation (RFC).

Herbert Hoover himself dismissed the organization, operation, and results of the National Credit Corporation as a failure. Hoover's epitaph was brief: "After a few weeks of enterprising courage, the bankers' National Credit Association became ultraconservative, then fearful, then finally died." ${ }^{\prime 1}$ Most historians, assuming that the NCC's "paltry" $\$ 10$ million in loans to distressed banks in its first three months of operation is the sum of the story, have followed Hoover's lead in castigating the bankers and the NCC. ${ }^{2}$ From the perspective of Iowa banks, however, the NCC can be viewed as a qualified success during intermittent periods from October 1931 to February 1932. America's banking industry sought to stave off bank failures by par-

1. Herbert Hoover, The Memoirs of Herbert Hoover, vol. 3, The Great Depression, 1929-1941 (New York, 1952), 97.

2. The adjective "paltry" is from James Stuart Olson, Herbert Hoover and the Reconstruction Finance Corporation, 1931-1933 (Ames, 1977), 31. The same adjective is used by David M. Kennedy, Freedom from Fear (New York, 1999), 83. See also Gerald D. Nash, "Herbert Hoover and the Origins of the Reconstruction Finance Corporation," Mississippi Valley Historical Review 46 (1959), 455-68; Albert U. Romasco, The Poverty of Abundance: Hoover, the Nation, the Depression (New York, 1965), 87-91, 181-82; Harris G. Warren, Herbert Hoover and the Great Depression (New York, 1967), 140-42; William E. Leuchtenburg, The Perils of Prosperity, 1914-1932 (Chicago, 1966), 257; Anthony J. Badger, The New Deal: The Depression Years, 1933-1940 (New York, 1989), 47; and Michael E. Parrish, Anxious Decades (New York, 1992), 250-51. 
ticipating in a massive cooperative effort and by providing liquidity loans to troubled banks. True, the NCC did not create new money, finance new factories, stimulate additional credit, or firm up bond prices. But the NCC did prevent dozens of bank failures - that can be seen in Iowa alone-and it did inject some renewed confidence in banks at certain intervals. Perhaps its most useful service was establishment of an organizational floor for the launch of the Reconstruction Finance Corporation (RFC) in February 1932. The lowa bank perspective from October through February provides a counter view to the historical assessment of "failure."

HOOVER first broached the idea of a "National Credit Association" to the Federal Reserve Advisory Council on September 15, 1931. ${ }^{3}$ Then, following England's abandonment of the gold standard on September 21, he met with George Harrison, president of the Federal Reserve Bank of New York; Andrew Mellon, Secretary of the Treasury, and his assistant, Ogden Mills; and Albert Wiggin, chairman of the Chase National Bank of New York. To stabilize the precarious banking situation in the United States, Hoover called for a "unity of action in the face of unsettlement due to European economic events"; the underwriting of a $\$ 500$ million bankers' association led by New York City banks "to support weak spots in banking"; bank association loan advances to receivers of closed banks (about 2,000 had failed since the stock market crash of October 1929) "so as to pay some dividend upon deposits"; extension of bank eligibility in the Federal Reserve System; recreation of a War Finance Corporation with $\$ 1.5$ billion of resources; and a strengthening of the Federal Farm Loan agencies to reassure bondholders. ${ }^{4}$

3. The notation in Hoover's handwriting appears on a Federal Reserve Advisory Board meeting agenda: "These men met with the President at the White House. Here the Pres. first proposed the plan of the National Credit Association." Presidential Subject Files (hereafter PSF), Federal Reserve Board Correspondence 1931, box 159, Herbert Hoover Presidential Library, West Branch, Iowa (hereafter HHPL).

4. Again in Hoover's handwriting, "Programme proposed to Harrison, Mills, Mellon, and Wiggin Friday, September 25, 1931," PSF, Financial-Laval Visit Memoranda, box 1013, HHPL. 
Before proposing the NCC, Hoover had gathered critical information from his advisers. At Hoover's request, Assistant Secretary of the Treasury Ogden Mills provided an estimate of total hoarded currency and a month-by-month breakdown of bank failures since January 1, 1930, with national banks shown separately from state-chartered banks. In addition, Hoover asked Eugene Meyer, chairman of the Federal Reserve Board, for a "solution [to] the problem of frozen deposits in our closed banks" (which totaled about $\$ 2$ billion since the crash). In midSeptember 1931, the Federal Reserve staff had estimated the amount of currency hoarded to be a "rock-bottom minimum" of $\$ 400$ million-“"and may be as much as $\$ 700$ million." By the end of September 1931, Mills estimated that the total had climbed to $\$ 800$ million. If one adds frozen deposits in failed banks to the amount being hoarded by people who were afraid of banks, then about $\$ 3$ billion, or roughly 7 percent of total bank deposits, was cut off from circulation in the economy. ${ }^{5}$

Hoover then called a meeting of 19 New York bankers, held clandestinely at Treasury Secretary Mellon's Washington, D.C., apartment on Sunday, October 4. Attributing the existing economic paralysis to the prolonged business depression, the succession of financial events abroad, the failures of banks in increasing numbers, and the destruction of confidence and rising fear around the country, Hoover called for "concerted action on the part of our leading bankers and strong banks to avert a possible threat to our entire credit structure." He noted that 1,215 banks had failed and almost $\$ 1$ billion in failed bank deposits had accumulated in the first nine months of 1931. More than half of the failures had occurred since June, freezing an estimated $\$ 800$ million in deposits. The combination of currency hoarding, bank failures, and failed bank liquidation all compounded geometrically. Bank failures inevitably triggered more hoarding and necessitated asset liquidation to pay off depositors. Sound banks, fearing bank runs, sought to increase their

5. Hoover to Meyer, 8 September 1931, PSF, Federal Reserve Correspondence 1931, box 159, HHPL; Meyer to Hoover, 15 September 1931, with attached memorandum from Goldenweiser to Meyer, 14 September 1931 (quoted), ibid; Mills to Hoover, 1 October 1931, PSF, Financial Matters-Banking and Bankruptcy Correspondence, 1931, box 155, HHPL. 
liquidity by selling securities. The stock, bond, and commodity markets, with more sellers than buyers, continued to decline. Hoover knew that "changing the eligibility provisions of the Federal Reserve Act" - whether to require banks engaged in interstate commerce to join the Federal Reserve, or to expand the list of assets eligible for rediscount at the Reserve Bankswould require time, legislation, and congressional hearings. And time, Hoover believed, was running out. A better alternative, he concluded, was to establish a national credit association of all banks, to provide rediscount facilities on sound assets not then eligible at the Federal Reserve discount window. That, he hoped, would "restore confidence of bank depositors." He further suggested that a separate organization be set up to liquefy the deposits in failed banks. ${ }^{6}$

Hoover theorized that if bank failures could be checked, then hoarding would cease; if frozen bank deposits could be "thawed," then dollars would be put back to work in local communities; if confidence could be restored among bank depositors, then perhaps bankers and investors would be more inclined to buy rather than sell. Clearly, the first order of business was to stabilize the deteriorating economy. And far better, Hoover believed, if the stabilization effort could be effected in the private sector, without federal dollars and federal legislation.

It is not clear whether all or only some of the New York bank executives knew about Hoover's proposition in advance; whether all or some were so skeptical that it was doomed to failure from the beginning; or whether the bankers absolutely insisted on a War Finance Corporation as a quid pro quo for setting up the National Credit Association. 7 In any case, Hoover dictated a letter to George Harrison on October 5, while en route to Philadelphia to watch a World Series baseball game. Hoover confirmed that the New York bankers would "take the lead in immediate formation of a national institution with a capital of $\$ 500$ million," which would rediscount bank assets

6. Copy of Prepared Statement Read to Nineteen New York Bankers Held at Secretary Mellon's Apartment, Sunday, October 4, 1931, box 158, PSF, National Credit Corporation, Proposed Organization, HHPL.

7. Compare Olson, Hoover and the RFC, 24-25; and Parrish, Anxious Decades, $25-52,253$. 
"not now eligible in the Federal Reserve System in order to assure the stability of banks throughout the country from attack by unreasoning depositors." The same entity would loan against the assets of closed banks "to enable them to pay some early dividend to depositors." In return, Hoover agreed to seek legislation to recreate the War Finance Corporation "if necessity required." ${ }^{18}$

Although Congress was not in session, Hoover met with the leaders of both political parties on October 6 and issued a press release to inform the nation of the $\$ 500$ million bankers' organization. He reported that $\$ 150$ million, or 2 percent of the net time and demand deposits of New York City clearinghouse banks, had already been pledged. George Harrison and Ogden Mills, however, had convinced him that NCC loans on the assets of failed banks were unrealistic. "The technical difficulties of disposing of the assets of closed banks [through the NCC] as well as the amounts involved," Harrison argued, "make it seem impossible to tackle this part of the program. ${ }^{\prime \prime}$ The inability to free up failed bank deposits left an enormous void in Hoover's attempt to revitalize confidence in banks. But given the momentum he had generated among bankers and legislators, and the immediate need to inspire confidence and mitigate fear, he opted to proceed. Hoover's announcement of the National Credit Corporation was carried with banner headlines in the nation's newspapers the following morning, October 7.

FOLLOWING HOOVER'S ANNOUNCEMENT, bankers across the country mobilized frantically to meet Hoover's challenge. Hoover knew that 297 banks nationwide had failed from August 28 through September 30 . He probably did not know that 44 of the failures, or 15 percent of the total, were Iowa banks. Nor did he probably know that 25 more Iowa banks had failed by October 7, the day he announced the NCC. In about 5 weeks, more than 70 Iowa banks, including a few national banks, had closed. $^{10}$

8. Hoover to Harrison, 5 October 1931, PSF, Federal Reserve, Correspondence, 1931, box 159, HHPL.

9. Harrison to Hoover, 7 October 1931, ibid.

10. Report of the Special Committee on Banking and Agricultural Credit Facilities, in Proceedings of the Forty-Sixth Annual Convention of the Iowa Bankers 
Coincidentally, a group of Iowa bankers and regulators happened to be meeting in Des Moines on the morning of October 7. They greeted Hoover's NCC announcement as a godsend. The officers of the Iowa Bankers Association had called a meeting of their Council of Administration, Group Secretaries, and three to four representatives from each of their eleven (geographic) groups. Others in attendance included L. A. Andrew, state bank superintendent; all members of the State Banking Board; and J. B. McDougal, governor of the Federal Reserve Bank of Chicago. The minutes noted that "the meeting would have been called several weeks before had there not been the well-founded apprehension that it would have attracted too much attention and only added, through any publicity that might have gotten out, to the general serious situation that was daily seemingly getting worse." If bank failures were the primary indicator, Iowa's banks were probably more in need of help than those in any other state of the nation. Accordingly, the IBA wired Hoover on the afternoon of October 7 that "the officers and other members of this Association and your native state are delighted to say that your constructive program has aroused profound interest. A committee has today been appointed with authority to do all within their power to work through the Federal Reserve System along the lines laid down in your statement. ${ }^{\prime 11}$

The Iowa bankers' reaction to Hoover's announcement was mirrored in correspondence to the White House. Joseph Galcz of Chicago could hardly contain his praise when he noted that "the world series baseball game which you attended was filled with thrills and excitement and with brilliant plays, however, when you returned to Washington it is evident that you were filled with the spirit of winning your game from the Club of depression; when you hit that half-billion dollar ball over the

Association (Des Moines, 1932), 343 (hereafter IBA Proceedings, 1932); "Changes that have taken place among State Supervised Banks in IOWA during October 1931," 2 November 1931, File "Bank Changes," box 269, Iowa Bankers Association Archives, Special Collections, Parks Library, Iowa State University, Ames, Iowa (hereafter IBAA).

11. Report of the Special Committee, in IBA Proceedings, 1932, 343-44. 
left field wall in the park of depression, you became the hero of the day." ${ }^{\prime 2}$

If the reaction of other bankers, legislators, and private citizens was more restrained, it was still mostly positive. One exception was that of Senator Smith Brookhart of Iowa, who commented that "the plan is utterly inadequate to meet the needs of the situation and this is especially true of the farm loan situation. The President should get rid of Mellon and Meyer and call Congress into extra session in order that a really adequate and comprehensive program can be worked out." ${ }^{13}$

Brookhart's forecast of "utterly inadequate" was to prove true, of course, but that hardly dimmed the initial enthusiasm. Because Iowa banking officials happened to be meeting on October 7, the state "was all ready to undertake the business of the NCC in Iowa before that Corporation could develop itself sufficiently to indicate what was to be done. ${ }^{14}$

The organizers of the NCC-the New York bankspromptly prepared a "Plan of Organization and Operation." Hoover and Mills received their copies on October 15. Mills responded that the NCC's $\$ 1$ billion in gold notes "will be accepted as collateral for public deposits. ${ }^{\prime \prime 5}$ Within ten days of the October 7 announcement, the NCC had filed its articles of incorporation, issued a Plan of Organization and Operation, elected a board of 12 men, one from each of the Federal Reserve Districts, and held its first board meeting. By October 19 the board had appointed W. Harold Brenton, president of the Iowa-Des Moines National Bank, as chairman of the Iowa Loan Committee. Brenton had his committee selected by October 24, and a week later "National Credit Association No. 4 of the 7th Federal Reserve District," encompassing banks within the state of Iowa, had been formed as a subsidiary of the National Credit Corporation in New York.

12. Galcz to Hoover, 7 October 1931, PSF, Financial Matters-Banking and Bankruptcy, Correspondence, 1931, box 155, HHPL.

13. New York Times, 8 October 1931.

14. Report of the Special Committee, in IBA Proceedings, 1932, 350.

15. M. N. Buckner, chairman, NCC Organization Committee, to Hoover and Mills, 15 October 1931, and Mills to Buckner, 16 October 1931, PSF, NCC, box 159, HHPL. 
On October 21-23 and again on October 26-28, the IBA and the Iowa Loan Committee held eleven separate group meetings throughout the state to explain the purpose and organization of the NCC. Almost 1,400 Iowa bank executives attended one of the conferences. They were obviously relieved that frozen farm loans might yet be thawed with liquid funds. The meetings were followed by an Iowa Loan Committee mailing on November 7 that produced a positive response from over 80 percent of all Iowa banks. All committed to join the NCC and to subscribe 2 percent of their net time and savings deposits. Frank Warner, secretary of the Iowa Bankers Association, noted that "the plan is a novel one. There is no precedent to follow." Warner, whose state led the nation in bank failures and whose association's membership had declined by 20 percent since 1930, concluded that "there has been a 'right about face' in the public's attitude [toward banks] since the President's announcement." As in Iowa, the banking organizations in New York and other states initially embraced Hoover's concept with enthusiasm and commitment. ${ }^{16}$

IOWA BANKERS-like farmers, businesspersons, and bankers everywhere-could not have known that, effective with Britain's departure from the gold standard in September 1931, the next three months would be among the worst in American economic history. When bank failures multiplied and were highlighted by the press, people looked to the federal government for a solution. Hoover resisted any federal action until there was no other choice. Both Hoover and Iowa bankers preferred to await the initial results of the NCC.

Frozen farm loans in Iowa and elsewhere were only one of the growing economic concerns in the United States in 1931. As revenues waned in the auto and railroad industries, U.S. Steel instituted a 10 percent wage cut in September. As other large firms in other industries followed suit, an estimated 1.7 million industrial workers were eventually affected. ${ }^{17}$

16. Report of the Special Committee, in IBA Proceedings, 1932, 350-52; Frank Warner, "Pushing a Banker's National Finance Plan to Completion," 17 November 1931, p. 2, NCA Printed Matter, box 265, IBAA.

17. Badger, The New Deal, 47. 
Bond depreciation was another serious concern. In the New York Federal Reserve District an estimated 346 banks with deposits of $\$ 1.2$ billion and capital of $\$ 205$ million (exclusive of New York City clearinghouse banks) had shown "probable bond shrinkage" of \$137 million from the date of last examination. By December 1931 the shrinkage had nearly doubled to $\$ 238$ million, more than $\$ 30$ million in excess of total capital. A study noted that "if banks continue to be closed by reason of bond depreciation, the situation must become steadily worse." Railroad bonds, which "have been regarded as one of the best and most conservative investments," constituted more than one-fifth of all bonds outstanding. Removing them from the "legal list" would force additional sales of bonds held by trust companies, insurance companies, and trustees. In the New York District alone, reporting member banks had reduced their railroad bond holdings by $\$ 400$ million. The report concluded, "Banks cannot be expected to buy railroad bonds while there is a threat of railroad insolvencies and the probability of continued decline in the prices of these bonds. They cannot be expected to employ their funds freely while there is overhanging them the prospect of many bank failures, which carry with them the threat of currency withdrawals and panic. ${ }^{\prime 18}$

Unlike the banks in the New York District, Iowa banks were operating not just with the "prospect of many bank failures"; rather, Iowa banks were failing rapidly and successively during most of the last six months of 1931. W. G. Jackson, cashier of the Earlham Savings Bank in Earlham, Iowa, noted the criticism "heaped on the banks because they will not extend more credit to farmers." But he also noted that loans to farmers had caused the failure of most of the banks in Iowa. Jackson also pointed out "the bank's duty to its depositors who have enough confidence in the bank to place their money there. ${ }^{\prime 19}$

In the absence of a federal guarantee on deposits, a loss of depositor confidence ultimately doomed any bank to failure. Country bankers such as $\mathrm{H}$. A. Linder, cashier of the Reasoner

18. "STRICTLY CONFIDENTIAL: Banking Situation in the Second District," 8 December 1931, PSF, Federal Reserve, Correspondence, 1931, box 159, HHPL.

19. W. G. Jackson to “Gentlemen," 17 July 1931, Henry A. Wallace Papers, Special Collections, University of Iowa Libraries, Iowa City. 
Savings Bank, knew that only too well. "The country banker does not fear the bank examiner," he wrote, "but we do fear the attitude of the depositor. ${ }^{20}$ Historians who claim that banks were unwilling-as distinct from unable-to make loans fail to recognize that a bank's ability or willingness to loan was directly related to the stability of deposits. And deposit stability was directly related to depositor confidence.

The confidence of Iowa depositors in lowa banks was reflected in the state's bank deposit totals, especially in comparison to banks nationwide. Iowa bank deposits had been declining steadily since 1920 . For the 12 months ending June 30, 1931, the drop was about $\$ 53$ million, or 12 percent. During the last six months of 1931, Iowa banks lost another $\$ 156$ million, or 22 percent, compared to 11 percent for all of the nation's banks. Loans in Iowa banks declined by one-third in the same period, compared to just over 10 percent for all banks. Loans by statechartered Iowa banks declined by 39 percent, deposits by 36 percent. Primarily because of declining farm prices, deposit and loan deflation hit the predominantly rural state-chartered banks harder than it hit the city banks, where proportionately more federally chartered national banks were located. During the 1920s and 1930s Iowa typically led the nation in revenue from the sale of corn and hogs, and corn and hog prices declined faster than other farm prices in the last half of 1931. During that time, the average price paid by packers was $\$ 4.05$ per hundredweightless than half of the price paid in marketing year 1929-30. Corn prices were even worse. The ratio of hog prices to corn prices encouraged hog production. With hog prices at their lowest level in 35 years, Iowa's 10.5 million hogs (19 percent of the U.S. total) were a glut on the state's economy just like its failed banks. ${ }^{21}$

If deposit stability and corn and hog prices concerned Iowa bankers and farmers in the fall of 1931, so too did the problem of farm credit in general. According to Rex Yockey, Hamilton

20. H. A. Linder to Wallace, 20 July 1931, ibid.

21. Seventeenth Annual Report of the Federal Reserve. System (Washington, DC, 1932), 79, 183; Report of the [Iowa] Superintendent of Banking for the Year Ending June 30, 1931 (Des Moines, 1931), 17; ibid., 1932, 19; Charles P. Kindleberger, The World in Depression, 1929-1939 (Berkeley, CA, 1985), 186; U. S. Department of Agriculture, Yearbook of Agriculture, 1932 (Washington, DC, 1933), 226. 
County Farm Bureau agent in Webster City, the problems were fourfold. First, many Iowa communities had "no credit facilities or only partial facilities due to closed banks." Second, the "hysterical condition" or "lack of confidence" or "mental attitude of depositors makes it necessary to the banker to carry large amounts of his deposits in liquid form to meet possible withdrawals." Third, there was a "peculiar aspect" of Iowa law that entitled the farm mortgagor (generally a life insurance company, not a bank) to both title to the land and to crops produced on or rent received from the land. As a result, mortgaged farmers could not borrow short-term using growing crops as collateral. Finally, there was the position that mortgage-free farmers found themselves in if they wished to borrow for whatever reason. Such a loan was only eligible for rediscount with the Federal Reserve if it was secured by "grain in the bin." As Yockey put it, "If this man did not happen to have grain for security which would make it [the loan] liquid, he might be denied the loan." ${ }^{\prime 22}$

By fall 1931, the farm mortgage crunch was apparent in Iowa and surrounding farm states. The average per acre value of Iowa farmland had declined from \$210 in 1920 to \$128 in 1929 and to $\$ 109$ in 1931. In 1929 the prevailing amount that could have been mortgaged on Iowa farmland was $\$ 81.63$ per acre, or about 64 percent of the value; by late 1931, the average mortgage amount had declined by about one-third to $\$ 55.33$ per acre, or about 50 percent of the value. Moreover, the number of farm mortgage concerns "actively lending" had dropped by over 70 percent. During the 1920s, many farm mortgage lenders, including banks, had permitted their farm borrowers to pay interest only. By 1931, however, over 90 percent of all farm mortgage lenders required borrowers to regularly reduce loan principals. The crunch was especially pronounced in Iowa. Of an estimated nationwide total of $\$ 9.2$ billion in farm mortgage debt, which required $\$ 568$ million in annual interest, Iowa farms accounted for $\$ 1.1$ billion, with interest of almost $\$ 70$ million. Almost one-quarter of Iowa's gross farm income went to service farm mortgage debt, compared to 10 percent for the nation as a whole. The total dollar amount of mortgaged farmland in Iowa was about double that of

22. Rex Yockey to R. K. Bliss, 10 October 1931, PSF, Farm Matters, 1931, box 127, HHPL. 
California and Texas, the next two highest states, with combined arable crop acreage about five times that of Iowa. ${ }^{23}$

In short, deposit declines and marginal farm mortgage and operating loans had forced many lowa banks to close in the decade preceding 1931. The state had lost more than 900 of its banks since 1921; 208 failures, 12 percent of the U.S. total, occurred in 1931 alone. In the past decade, American bank failures had buried a total of $\$ 4.9$ billion in deposits, with almost $\$ 380$ million, or 8 percent, emanating from Iowa banks. Only Pennsylvania, with failed bank deposits of $\$ 424$ million, and Illinois, with $\$ 419$ million, exceeded Iowa's total. ${ }^{24}$ And there, the failures of large banks in Philadelphia and Chicago, which occurred mostly in 1931, inflated their state deposit totals. With a state population that was only one-third that of Philadelphia or Chicago, Iowa's bank failures had occurred sooner and were far more numerous and frequent. The combination of higher per capita deposits in failed lowa banks and higher per capita farm mortgage and related loans outstanding-coupled with the corn/hog glut and further declines in grain and pork pricesmeant that cash and asset values were probably declining faster in Iowa than in any other state.

President Hoover was certainly aware of the publicity given to bank failures and of weaknesses in the U.S. banking system. But in the fall of 1931 the most important need was to inject some confidence into the economy and provide the banks with breathing room. Iowa bankers were frustrated by the coverage that newspapers gave to bank closings, and Hoover's announcement of the NCC was probably designed to neutralize to some extent the public's reaction to those reports. James Traer, vice-president of the Farmers National Bank in Vinton, noted in September that "the Des Moines Register is rather making a feature of bank closings, publishing the day's closings in a column

23. "Farm Credit Situation in Iowa," 22 October 1931, p. 10, ibid; USDA, Yearbook of Agriculture, 1933, 699, 735. See also Patrick B. Bauer, "Farm Mortgagor Relief Legislation in Iowa during the Great Depression," Annals of Iowa 50 (1989), 23-62, esp. table 1, "Iowa Agricultural Economic Conditions, 1911$1940, "$ p. 24.

24. Eighteenth Annual Report of the Federal Reserve (Washington, DC, 1933), 207, 212. 
next to the obituaries." He wondered if these items might at least be scattered throughout the paper. J. P. Hess of the Carroll County State Bank believed that "such news spreads rapidly from mouth to mouth and increases the unrest." $\mathrm{H}$. M. Wilson, cashier of the State Bank of Lacona, told Frank Warner that he had "been checking up quite carefully among customers and they all say practically the one thing, 'we read the list of banks closed everyday and you can't blame us for taking our money out of the banks." ${ }^{\prime 25}$

Harry Allfree of Cedar Rapids offered Hoover a practical, if politically impossible, suggestion. Realizing that "when a depositor wants his money, he wants cash, not conversation, nor farmers' notes, nor any kind of security," Allfree suggested that "the average person has lost confidence in everything except his Government." He suggested that Hoover have Congress "pass a Resolution guaranteeing the deposits of National Banks." He pointed out that "you have charge of them now through your Comptroller of the Currency" (the regulator of national banks, distinct from state bank regulators), and that other banks should not be precluded from joining the national bank system. ${ }^{26}$ Allfree essentially proposed that national bank deposits be federally guaranteed and that state banks, if they could not meet minimum federal requirements, be eliminated from the system. Had Hoover been able to bypass or convince 48 state bank superintendents and 48 state banking boards, not to mention the 15,000-plus state-chartered banks, that the power of bank regulation and supervision should pass from state to federal hands, the later collapse of the industry might have been avoided. Once again, time and confidence were Hoover's biggest considerations, and during the month of October 1931, he did not believe that federal intervention was required; nor did he doubt that the NCC was capable of solving the bank liquidity crisis.

25. Traer to Warner, 30 September 1931, file "Press,". box 268, IBAA; Hess to Warner, 5 October 1931, ibid.; Wilson to Warner, 12 October 1932, ibid.

26. Allfree to Hoover, 22 October 1931, PSF, Financial Matters-Banking and Bankruptcy Correspondence, 1931, box 155, HHPL. 
IN A PRESS CONFERENCE on October 30, Hoover announced that a "very great change" had become evident in the financial situation of the country. Currency hoarding had been checked, gold shipments abroad had slowed, bank failures had dropped from an average of 25 a day to seven in the past week, and the price of wheat had advanced 10 cents a bushel. The New York Times opined that Hoover had advanced the NCC "as the main shaft of the machinery by which he hoped to pump life again into the business structures of the country, and it was obvious from his demeanor yesterday that he is finding much satisfaction in its operations up to this time." The daily trade journal, the American Banker, had announced, "National Credit Corporation Now Ready to Function," with the sub-headline "No Loans Made Yet; Perfection of Subsidiary State Associations Awaited."

The fact that no loans had been made yet concerned Walter Stewart, a former New York investment banker now serving as an administration adviser on banking. He suggested that there might be little substance to future NCC loan operations and was convinced that "in the existing mood of the [New York City] bankers, they cannot be depended upon, if left to themselves, to put the Credit Corporation into full and prompt operation." He urged George Harrison and Ogden Mills to "take vigorous action aimed at changing the state of mind of leading bankers in New York." He also advised that someone from the Treasury and Federal Reserve should oversee the "actual progress" of the NCC's operation. ${ }^{27}$

Stewart was especially concerned, perhaps at Hoover's behest, with the dilemma of closed banks and how to free up deposits in failed banks. There was no easy way to aggregate the total amount of assets and liabilities of all closed national banks to produce a "combined detailed balance sheet." Every closed national bank had its own bankruptcy receiver, usually a political appointee who proceeded at his own pace with few federal guidelines. Stewart discovered that the U.S. Treasury and the Comptroller of the Currency had no policy for final liquidation

27. New York Times, 31 October 1931; American Banker, 29 October 1931; Stewart to Mills, Memorandum for Mr. Mills, 24 October 1931, PSF, NCC Correspondence, box 158, HHPL. 
or eventual reopening of closed national banks. He recommended that the Treasury proceed "through the Federal Reserve Banks" to either the NCC or the larger New York City banks "with a view to obtaining credit upon selected assets of closed banks and making cash distributions to depositors. ${ }^{\prime 28}$ Nothing came of Stewart's proposals. The "politics" of bank regulation-which agency had what role in the case of failed banks, the gathering of aggregate data, the appointment of receivers, and the ultimate disposition of each failed bank-was left unresolved.

Iowa bankers, while no doubt concerned about failed banks and their depositors, were probably more concerned about salvaging the state's remaining banks. Bank survival depended on having sufficient liquid funds on hand. Because bankers desired to build liquidity, the NCC Iowa Association envisioned that the dollar amount of loans requested might exceed the amount of "subscription funds" required that were payable to New York headquarters and based on 2 percent of net deposits. Accordingly, the Iowa Loan Committee sent two of its members to New York to secure "concrete assurance that funds would be available." By early November, the Loan Committee had sent out several hundred letters to prospective borrowing banks urging that they "prepare their collateral and applications in complete form" to submit to the committee. Frank Warner reminded bankers that the NCC "is a gigantic undertaking, an enterprise that is to operate in 48 states and the District of Columbia and with approximately 22,000 American banks." Being first in line and best organized might streamline loans to Iowa banks in need. ${ }^{29}$

Delays were inevitable. Whether they were attributable to the New York bankers ignoring the exhortations of Hoover and Mills to "get moving," as one historian claims, or whether the delays occurred at the local level, it seems that the local associa-

28. Ibid.

29. Report of the Special Committee, Bulletin No. 2 of the Iowa Credit Committee, in Proceedings, 1932, 350-51; Frank Warner, "To: Sub-Loan Committee for Iowa," 7 December 1931, Iowa NCA Committee Correspondence, box 266, IBAA; Warner, "Pushing a Banker's National Finance Plan to Completion," 3. 
tions and the local loan committees had their hands full. ${ }^{30}$ Frank Warner asked Charlie Fisher, secretary/treasurer of the NCC Michigan Loan Committee in Detroit, about his committee's status, policy, and operations. Fisher admitted that while his committee had met, it had not approved any loans. Its problems included: (1) obtaining a copy of the latest examination report from the State Banking Department or the Comptroller of the Currency; (2) determining whether or not the prospective borrower was in basically sound condition; (3) determining whether the bank was operating for the community at large or for "a few wealthy individuals for their own convenience"; and (4) determining whether there was "an economic necessity for the bank in its particular locality." In addition, collateral had to be evaluated. "We are preparing to receive city and farm mortgages, collateral real estate mortgages, chattel mortgages, stocks, bonds, secured and unsecured notes of individuals, firms, or corporations substantiated by a first-class financial statement. ${ }^{\prime 31}$ In contrast, the Iowa Loan Committee, because of anticipated requests from farm banks, would have been more concerned with bank loan policies pertaining to grain and livestock. Were farm borrowers required to administer serums to prevent hog cholera? Were crop production expenses in line with yields per acre? Could other sources of farm revenue, such as eggs and cream, be used to service operating loans?

Dozens of local NCC Association Loan Committees around the country (New York state alone had eight) had to feel their way along, relying on the tools and legal forms that bankers knew best, and sometimes traveling hundreds of miles to a central meeting point. Contrary to some historical interpretations, the bottleneck on booking NCC loans was more at the local association level rather than in New York, at least through December. $^{32}$

\section{Olson, Hoover and the RFC, 28.}

31. Warner to Charles T. Fisher Jr., 9 November 1931, Iowa NCA Correspondence, box 265, IBAA; Fisher to Warner, 12 November 1931, ibid.

32. Congressional testimony in mid-December 1931 confirmed that the NCC had advanced only about $\$ 10$ million in loans. Michael Parrish comments in Anxious Decades, 251, that "sober, cautious, judicious bankers all, the managers at the NCC ... feared for the liquidity of the National Credit Corporation!" 
By the first week of December, bankers around the country, Iowa bankers included, had begun to lose their enthusiasm for the NCC. Hoover later noted that "by the end of November 1931, our small burst of recuperation had petered out, and all the ground we had gained-and more-was quickly lost. ${ }^{133}$ Here was the low point of the NCC, leading to Hoover's decision to ask Congress to revive the War Finance Corporation. Louis Kurtz, chairman of Iowa's largest bank, the Iowa-Des Moines National, wrote to Hoover to urge that the War Finance Corporation take the place of the National Credit Corporation. While he thought that the NCC "is doing a fine piece of work, they cannot do so sufficient to properly care for the situation existing in the agricultural districts of the middlewest. ${ }^{\prime 34}$

Kurtz's nephew, W. Harold Brenton, was both president of the Iowa-Des Moines National Bank and chairman of the NCC Iowa Association's Loan Committee. Both men were aware that the Iowa Loan Committee could not prudently accept Iowa farm and chattel mortgages as collateral for NCC borrowings with so much farmland in bankruptcy, so many banks in liquidation, and corn and hog prices still declining. Credit had all but shut down in the state, whether from banks, building and loan associations, insurance companies, Federal Land Banks, or farm implement dealers. As Iowa Governor Dan Turner noted in a telegram to Hoover on December 7,

We would respectfully call your attention to the very serious situation in Iowa and adjoining states. For the first time in a generation, it seems to be impossible for our farmers to obtain even the most conservative loan on their land. This is adding a heavy burden to an already serious situation. Something should be done as soon as possible to ease the farm loan market not only to aid the farmer but also the smaller banks in agricultural communities. It is now apparent that the War Finance Corporation should be reinstated at once or similar method provided to meet the emergency. ${ }^{35}$

33. Hoover, Memoirs, 3:97.

34. Kurtz to Hoover, 3 December 1931, PSF, War Finance Corporation, box 92 , HHPL.

35. Turner to Hoover, 7 December 1931, ibid. 
ON DECEMBER 7, 1931, President Hoover proposed to Congress that the War Finance Corporation be reconstituted and renamed the "Reconstruction Finance Corporation." The corporation was intended to replace or supplement what the National Credit Corporation had failed to do, or could not do, or had not done, depending on one's interpretation. Hoover proposed that Eugene Meyer chair the RFC as he had done for the WFC, and that the RFC legislation be passed as soon as possible.

The House and Senate Banking Committees held hearings before Christmas and challenged the results of the NCC to date. Senator Bulkley of Ohio told Meyer that the NCC was not even making loans. Meyer replied that loans were being made, but he did not know how many or the amount. Bulkley believed that the NCC had failed. He had been told that "the bank pool found the situation such that loans could not be made with safety and that the banks wanted [the RFC] to take over loans which they considered doubtful risks." Iowa Senator Smith Brookhart, never one to hold back if there was a chance to attack "Wall Street," reviewed the history of the WFC and asked Meyer, "Isn't the present situation brought about by the big financial crowd making foolish loans after the war? You keep saying that the proposed bill will help the small banks; what about the big New York banks?" Meyer responded blandly, "It will help all the banks and the country generally." That hardly satisfied Senator Bulkley. He thought that the NCC "ought to function before we put this new corporation [the RFC] into effect." Moreover, he feared that frozen banks assets were going to be unloaded onto the RFC.

But that was precisely the point, responded Melvin Traylor, president of Chicago's First National Bank, in his testimony. Traylor was a Democrat and a member of the Federal Reserve Advisory Council to whom Hoover had first proposed the concept of a "National Credit Association" the previous September. Traylor, like Hoover initially, saw the NCC as a temporary, voluntary, and emergency entity only. "To pursue this policy to the end," he argued, "would mean tying up \$500 million in slow assets," which would aggravate the problem of the banks and be of no aid to the economy. The problem of financing marginal assets that ranged from deteriorating railroad bonds to delin- 
quent farm mortgages, he continued, should be the function of a government organization, not the banking industry. While Eugene Meyer thought the biggest problem was that "strong banks are afraid of the weak ones," Melvin Traylor believed that it was "a lack of public confidence in today's banking system." ${ }^{\prime 36}$ Both were right.

THE NCC finally made its first loans just after Hoover's call in December for legislation to erect the RFC. It made more loans through February 1932, when Congress decisively approved the RFC. Bankers and NCC officials realized that the RFC legislation would easily pass despite some scattered opposition and that NCC advances made on marginal bank assets could probably be "taken out" or replaced by RFC funds. Senator Carter Glass, ranking minority member of the Senate Banking Committee, acknowledged that some NCC assets would have to be made eligible for rediscount by the Federal Reserve Banks. The result was that the NCC served as a bridge for banks tottering between failure and dire need of liquidity assistance. ${ }^{37}$

Although most state associations or loan committees were. initially too poorly organized to process loans effectively, the Iowa Loan Committee, which was organized earlier and more efficiently than most of the others, proved its worth. By yearend 1931, a total of only about $\$ 10$ million had been loaned nationwide. One-third of that total went to three Iowa banks. Three million dollars had been advanced to the closed American Savings Bank in Davenport, soon to be reopened as the newly capitalized Davenport Bank and Trust Co., and another $\$ 650,000$ had been advanced to two banks in Des Moines. In addition, NCC loans in late December to banks in North Carolina, Mississippi, Georgia, and Louisiana helped to stem a regional crisis in the South. ${ }^{38}$

After struggling to get organized during its first three months of operation, the NCC finally got rolling in the next three weeks.

36. New York Times, 19 and 22 December 1931; U.S. Congress, Senate, Hearings on S. 1: Creation of a Reconstruction Finance Corporation, 72d. Cong., 1st sess., 176, 263.

37. Olson, Hoover and the RFC, 29-30; Proceedings, 1932, 353.

38. Time, 28 December 1931; see also Olson, Hoover and the RFC, 30. 
By January 22, 1932, the day Hoover signed the RFC legislation, the NCC, through its local associations, had made total loans of $\$ 145$ million to 644 banks in 10 of the 12 Federal Reserve districts. Some $\$ 449$ million in debentures had been subscribed and $\$ 429$ million in gold notes were reported signed. In the Richmond and Atlanta districts, more than $\$ 30$ million had been loaned, excluding almost $\$ 17$ million in commitments to be drawn on in the next two weeks. In the Boston district, $\$ 14.8$ million had been advanced. An additional $\$ 10$ million had been committed to banks in the state of Maine alone. New York district banks had borrowed only $\$ 8.3$ million, but $\$ 15.3$ million was committed to northern New Jersey banks. And although the St. Louis district had borrowed only $\$ 6.7$ million, commitments pending totaled $\$ 11.5$ million, $\$ 5$ million to troubled Arkansas banks alone. In all, 3,940 banks, or almost one in every five banks in the United States, joined the National Credit Corporation within 14 weeks of Hoover's first public announcement. ${ }^{39}$

In the Chicago Federal Reserve district, which included Iowa, 141 banks borrowed a total of $\$ 12.2$ million by January 22 , not including $\$ 6.2$ million in commitments. ${ }^{40}$ In the Iowa Association, a total of 220 Iowa banks "manifested some direct or indirect interest" in joining the NCC. Gross subscriptions actually received totaled $\$ 1.1$ million from 51 Iowa banks, while another $\$ 1.2$ million from 97 other banks were "in process of being gotten in proper form" by the time the RFC came into existence. In addition, 40 Iowa banks borrowed a total of $\$ 2$ million from the NCC, exclusive of loans made earlier to the Davenport and Des Moines banks. ${ }^{41}$ The NCC also loaned $\$ 4.7$ million nationwide to 28 banks that were subsequently closed by January 22 . The only failed-bank loan in Iowa was for $\$ 160,000$ to the Farmers Loan and Trust Co. of Iowa City. Its failure in 1932 left the city with the distinction of being the largest in Iowa without a bank until the newly chartered Iowa State Bank and Trust Co. was

39. "National Credit Corporation-Subscriptions to Gold Notes, Loans Made, Etc., as of January 22, 1932," PSF, Financial Matters, NCC Board of Directors, box 158 , HHPL.

40. Ibid.

41. Report of the Special Committee, part 3, "National Credit Corporation," in Proceedings, 1932, 353. 
formed later that year. ${ }^{42}$ Still, 770 other banks around the country had failed since the corporation was organized. Undoubtedly, the Iowa and nationwide total would have been even higher without the NCC.

Certainly the relatively successful NCC experience in Iowa was tainted with frustration. Harold Brenton summarized it best when he praised Frank Warner, the IBA's indefatigable secretary, who also served as secretary/treasurer of the Iowa Loan Committee. The work of the NCC, Brenton wrote, "was certainly a tedious, tiresome, aggravating job. You knew that it would not succeed thoroughly but you still went ahead and did the best you could with the restrictions placed upon you." Warner had sent out 33 bulletins to IBA members and to the loan committee since early October, the latest concerned with, among other bureaucratic details, authority to change "Articles of Agreement" of banks having subscribed and in the process of subscribing; obtaining "Certificate of Election of Officers" and specimen signatures; and obtaining "Certified Copy of Bank Charter." The paperwork was overwhelming. Before considering a loan, the NCC Chicago office required three executed copies of a loan application; three copies of "Opinion of Counsel"; three copies of "Resolution of Board"; two copies of "Note for Borrowing Bank"; three copies of "Security Offered by Bank"; two copies of certified financial statements; two certified copies of the bank charter; and two certified copies of board resolutions or bylaws relating to loans to the bank. With each amendment or change in form, Warner's office had to stop and correct all the copies of the different forms for each bank, which "runs into correcting thousands of these forms at a time." During the fall and winter of 1931-32, Warner had two teams of six secretaries each, one team working from 7:00 a.m. to 5:00 p.m., the other from 5:00 p.m. to 3:00 a.m. every day except Sunday. ${ }^{43}$

42. Des Moines Tribune, 20 January 1932.

43. Brenton to Warner, 15 February 1932, NCC Correspondence, box 266, IBAA; Warner to "Sub-Loan Committee" for Iowa, re., Additional amendments on subscription forms requested by the National Credit Association No. 1 in Chicago (original underline), 7 December 1931, NCC Forms Amendments, box 266, IBAA; "Forms required by the National Credit Association Number One of the Seventh Federal Reserve District to be executed by borrowing banks," undated but received on 29 November 1931 by National Credit Association 
Warner was no doubt discouraged by the NCC's efforts and results, but the NCC did help to salvage a few IBA member banks. While $\$ 145$ million in total NCC loans to banks hardly represented an overwhelming success, the distribution of loans to marginal banks in troubled economic spots was crucial to relieving liquidity pressures. Continued deflation, loan liquidation, and deposit outflows resulted in contracted bank balance sheets. The results in Iowa indicated that banking and agricultural credit would require unprecedented federal intervention if either or both were to be salvaged.

THE REVIVAL of the War Finance Corporation (later renamed the Reconstruction Finance Corporation) was both the federal government's strategic attempt to deal with an economy that had been in almost continual decline since mid-year 1929, and Herbert Hoover's tactical response to the "failure" of the National Credit Corporation. Hoover and subsequent historians have generally ignored three crucial intervals between October 7, 1931, when the NCC was first announced, and February 17, 1932, when the RFC began making its first loans. The first period was October 7-30, when rampant bank failures were halted, the financial markets revived somewhat, and business regained some lost confidence. The second period was the last half of December, when critical NCC loans stabilized some key banks in Iowa and throughout the South. The third period was January and early February 1932, by which time the local loan committees had streamlined their procedures and NCC loans were flowing freely. The same loan committees and streamlined procedures remained intact for the RFC to utilize, enabling it to loan approximately $\$ 22$ million to 325 Iowa banks by June 1 . Without the NCC's committees and procedures, the RFC could not possibly have analyzed, processed, and booked that many loans that quickly.

No. 4 of the Seventh Federal Reserve District (the Iowa Association), ibid; Report of the Secretary, 1931-1932," in Proceedings, 1932, 338.

44 . Of the approximately $\$ 22$ million in RFC loans to Iowa banks through May $1932, \$ 14.3$ million was approved by the Iowa Loan Committee, $\$ 4$ million was approved in Chicago, and only $\$ 3.3$ million was sent directly to Washington and approved. Although loan funds were ultimately advanced by the RFC's 
The question remains whether Hoover saw the NCC as a temporary, stopgap measure-the RFC being its inevitable sequel because the NCC had "failed" -or whether he saw the NCC in 1931 as the catalyst to "win the war" against the Great Depression. It seems that Hoover, at least initially, saw salvation to the bank liquidity crisis in the NCC. By November, though, with mounting railroad problems, a declining bond market, and volatile price swings on commodity markets, it would have been unrealistic to believe that a few hundred million dollars in interbank liquidity loans could have salvaged the deteriorating economy. Both Hoover and the bankers were frustrated at times by the NCC and disappointed in the results, at least through mid-December. Yet the contemporary evidence confirms that Hoover-contrary to the lamentations recorded in his memoirs twenty years later-thought the NCC served a useful purpose. In a letter to Mortimer Buckner, president of the NCC and chairman of the New York Trust Co., on December 14, 1932, about a year after he called for RFC legislation before a joint session of Congress, Hoover requested "data" on the NCC "as would form the basis of a future historical account of what was really a very great public service. ${ }^{\prime 45}$ With the completion of the NCC's work, Hoover expressed his gratitude for a job well done.

While frozen deposits in failed banks during December 1931 and January 1932 alone totaled over $\$ 400$ million, the NCC booked loans to almost 650 banks amounting to $\$ 145$ million. Moreover, the corporation actually raised $\$ 449$ million in pledged subscriptions through three "installment draws" during January 1932. Finally, the local NCC Loan Association committees provided the infrastructure for the RFC and were of inestimable aid in launching the new program.

Washington headquarters, most of the applications and processing, especially from smaller banks, was handled at the local level or at one of the 33 regional offices. At its peak the RFC processed hundreds of loans each week, but only a relative handful found their way to the RFC board of directors in Washington for actual deliberation. See "Loans to June 1, 1932 of Reconstruction Finance Corporation," in Proceedings, 1932, 354.

45. Hoover to Buckner, 14 December 1932, PSF, Financial Matters-NCC Correspondence, 1932, box 158, HHPL (emphasis added). 
In 1952 Hoover wrote an obituary for the NCC-"ultraconservative, then fearful, then finally died" - and lamented the delay by Congress in passing his RFC legislation. Like the historians who have followed in his wake, he ignored the fact that some banks and bankers were doing some critical liquidity financing through the NCC during this difficult period. It is true that the amounts were small and the results were mostly ineffectual, especially in view of the collapse of the banking system a year later. The NCC was the collectivist effort of an industry that, with Hoover's prodding, attempted to deal with its own hemorrhaging and salvage its failing brethren.

Historian William Leuchtenburg, writing in 1966, noted that "by the autumn of 1931, bankers had carried out the policy of deflation so relentlessly that they were caught in their own web. Once deflation threatened the financial structure, bankers were curiously unwilling to experience the spiritual benefits of chastening." Leuchtenburg blamed the banks for causing deflation, forgetting that plenty of "chastening" had already affected the numbers of farm community banks and dollars of frozen deposits in the previous decade. He concluded that "the bankers demanded government protection from the consequences of deflation to themselves. ${ }^{\prime 46}$

Instead, the NCC was a vintage Hoover strategem that produced some qualified success in an economy going from bad to worse. It demonstrated that banks and the banking system could be saved: state-chartered banks and state bankers associations were the keys to the NCC organization and operation, probably more so in Iowa than in any other state. If the perspective from Iowa is any indication, then the National Credit Corporation was not simply a product of a demand from bankers for government protection. If it was not an unqualified success, neither was it a total "failure."

46. Leuchtenburg, Perils of Prosperity, 257. 
Copyright of Annals of Iowa is the property of State of Iowa, by \& through the State Historical Society of Iowa and its content may not be copied or emailed to multiple sites or posted to a listserv without the copyright holder's express written permission. However, users may print, download, or email articles for individual use. 